\section{Autoantikörper gegen MuSK}

W. Stöcker und C. Krüger

Euroimmun Medizinische Labordiagnostika AG, Lübeck, Deutschland

Synonym(e) MuSK-Antikörper; Autoantikörper gegen muskelspezifische Tyrosinkinase

Englischer Begriff autoantibodies to the receptor tyrosine kinase MuSK

Definition MuSK ist ein transmembranöses, mit dem Acetylcholinrezeptor assoziiertes Protein der neuromuskulären Verbindung (motorische Endplatte).

Funktion - Pathophysiologie Die Funktion der muskelspezifischen Tyrosinkinase ist noch weitgehend unklar. Wahrscheinlich spielt MuSK eine Rolle bei der Vermittlung der Agrinwirkung auf die Aggregation des Acetylcholinrezeptors. Die bei Myasthenia gravis auftretenden Autoantikörper gegen MuSK sind gegen das extrazelluläre $N$-terminale Ende der MuSK gerichtet.

Untersuchungsmaterial Serum oder Plasma.

Probenstabilität Antikörper sind bei $+4{ }^{\circ} \mathrm{C}$ bis zu 2 Wochen lang beständig, bei $-20^{\circ} \mathrm{C}$ über Monate und Jahre hinweg.
Analytik Die Bestimmung erfolgt mittels Radiorezeptorassay (RRA) oder $>$ Enzyme-linked Immunosorbentassay.

Referenzbereich - Erwachsene $<0,05 \mathrm{nmol} / \mathrm{L}$.

Referenzbereich - Kinder $<0,05 \mathrm{nmol} / \mathrm{L}$.

Indikation Myasthenia gravis (okuläre und generalisierte Form), insbesondere wenn keine $>$ Autoantikörper gegen Acetylcholinrezeptoren (ACHRAB) nachweisbar sind.

Interpretation Die Myasthenia gravis, eine neuromuskuläre Autoimmunerkrankung, ist häufig mit dem Nachweis von Autoantikörpern gegen Acetylcholinrezeptoren (ACHRAB) im Blut assoziiert. Bei 10-20\% der Patienten mit einer generalisierten Myasthenia gravis sind diese jedoch nicht nachweisbar (bislang sogenannte seronegative Myasthenie). In zirka 40-70 \% der Myasthenie-Fälle ohne ACHRAB werden Antikörper gegen MuSK gefunden. Zusammen mit den ACHRAB lassen sich mehr als $90 \%$ der MyastheniePatienten serologisch erfassen.

\section{Literatur}

Hoch W, McConville J, Helms S et al (2001) Auto-antibodies to the receptor tyrosine kinase MuSK in patients with myasthenia gravis without acetylcholine receptor antibodies. Nat Med 7:365-368

Vincent A, Bowen J, Newsom-Davis J et al (2003) Seronegative generalised myasthenia gravis: clinical features, antibodies, and their targets. Lancet Neurol 2:99-106 